Fenyo, Mario. "Dés, Mihály. 2013. Pesti barokk ['Budapest-Style Baroque']. Budapest: Magvető. 552 pp.”

Hungarian Cultural Studies. e-Journal of the American Hungarian Educators Association, Volume 8 (2015):

http://ahea.pitt.edu DOI: 10.5195/ahea.2015.195

\title{
Dés, Mihály. 2013. Pesti barokk ['Budapest-Style Baroque']. Budapest: Magvető. 552 pp.
}

\section{Reviewed by Mario D. Fenyo, Bowie State University}

Imagine how disconcerted I must feel, having discovered that I am not as valiant a warrior in the struggle for women's rights, let alone women's liberation, as I believed. I had read about one third of Pesti barokk, Mihály Dés' rather long novel, when I found out that it is surrounded by controversy, to-wit that it is considered a "misogynistic piece of writing" according to an anonymous reviewer because the scores of women appearing in it chapter by chapter are treated as mere "objects" by the protagonist, the novel's fictional narrator who is allegedly writing up his memoirs. Moreover, this view concerning the protagonist, and perhaps the author of this work as well, may intimate that I, the author of this review, too, may be their accomplice as no better than a "male chauvinist," since it had simply not even occurred to me that there is misogyny involved here, presumably because I am not sensitive enough. But it is occurring to me as a possible interpretation, as I now read that the author was rejected by a respected writers' association in Hungary and that it may have been at least partly because of the misogyny in his writing.

I may be treading in the footsteps of my father, writer Miksa Fenyo, who in 1912 wrote an essay on Jean-Jacques Casanova, who put Casanova's memoirs into my hands during my early teens, and who never indulged in moralizing literary criticism, except for concluding that the Venetian hero of the boudoirs must have been a liar. All these surmises turn out to be of little avail: upon rereading and reevaluating the novel by Dés I am still not shocked, neither by its rather mild eroticism nor by the way women are portrayed in the fictional memoirs comprising this novel. Indeed, the girlfriends of this fictitious recorder of events, János Koszta (suspiciously reverberating Jean-Jacques Casanova on the one hand and János Kádár on the other) are often described as more or less desirable objects, or like weak and submissive recipients. They also tend to be rather easy (or, put more crudely, like sluts), a deplorable trait in the eyes of the "hero" or "anti-hero." In my eyes, though, they are not to be deplored for their permissiveness but, on the contrary, they ought to be cheered on without any reservations.

Although most of the novel is enjoyable reading, perhaps it should not be even presented as erotic, because it is not particularly successful in this regard. The exploits of this fictional hero bear no comparison to those of Casanova, nor to those of Mozart's Don Juan (in his Don Giovanni opera) as the protagonist not only falls short of Don Juan's "1003 conquests," but he fails to seduce even a single woman. He is no Frank Harris, Victor Hugo, or any other famous womanizer of the Western world; rather, this fictional anti-hero is more of a Schlemiel. If we compare the novel by Dés to the secret diary of Géza Csáth (1887-1919), perhaps the most famous and most despicable of Hungarian womanizer-writers (about which see Mateusz Chmurski's review article, titled "The Wedding Gown Writes Back," in this vol.), then we are somewhat more in tune with relevant counterparts to Schlemiel Koszta. It may well be that rather than writing an erotic novel Dés has in fact written a most successful social (hi)story even

$($ (c) $)$ EY

ULIS D-Senle 
Fenyo, Mario. "Dés, Mihály. 2013. Pesti barokk ['Budapest-Style Baroque']. Budapest: Magvető. 552 pp."

Hungarian Cultural Studies. e-Journal of the American Hungarian Educators Association, Volume 8 (2015): http://ahea.pitt.edu DOI: 10.5195/ahea.2015.195

though he never intended to write a history of any kind. Novels can be truly successful as social histories of sorts when carrying no such intentionality. In my own teaching career, I often resort to some work of fiction as a kind of "secondary text" attesting to the cultural reality of a place, era, or event; I take this approach for various reasons, including that my students are so much more ready to read interesting fiction -- and learn from it -- than to read plain, "straight" and often boring history books.

In the case of Pesti barokk, the argument about the novel's status as a social history becomes even more complex, because this book -- whose first edition appeared in 2013 and the second in 2015 -- begins in 2008, or perhaps some twenty-five years earlier, although according to the author it does not describe the immediate social environment of the mid-1980s. Rather, even though the novel focuses on the life of one János Koszta in 1984, much of the work is actually made up of the protagonist's flashbacks to earlier decades. In fact, some of the chapters refer to actual historical events of earlier periods, some of which I have either experienced personally or studied as a historian. These may be the events of the Kádár period (the broader definition of which covers some four decades, since the early 1950s to the late 1980s), or of the earlier World War II and the Holocaust, and in any event they leave varying impressions on the personae dramatis in the book. As for the events of the 1970s, more specifically, I can cross-refer to some of these with my own historical readings and sometimes with my own personal experiences during my visits to Hungary of the time.

The specific details as well as the general atmosphere of the period as conveyed by the fictional protagonist and by other characters have possibly been experienced by the author, who emigrated from Hungary as late as 1984, and they are largely negative; but they are not negative to the point of becoming unrealistic and incredible. One example of the negative yet realistic reality of the time, and sorrowfully of today's Hungary as well, is the small-scale, every-day corruption, like the tips collected by underpaid medical personnel. Another case in point is the issue of housing conditions that allow for little or no privacy. In this novel the adventures, meaning the "love affairs," are carried out, or fail, within earshot of the grandmother who owns and inhabits the apartment.

The structure of the novel deserves to be noted for its originality and complexity. The protagonist who is the author of the inner memoirs is at times easily confused with the author of the novel. To add to the reader's bafflement, one entire chapter (11) is written in the form of a one-act play in which the narrating subject, the novel's "I" ('Én' in Hungarian) is both authoring the events and replicas and participating in the dialogues. Then there are several chapters written in the form of a movie-script, and one of them features this $E n$ as seeing himself hiding behind a bush and spying on his girlfriend of that moment. Dés spent many years in Barcelona, in selfimposed exile, away from the spirit of the times and away from the Hungarian environment altogether. Indeed, there are traces of the Spanish or Latina presence in the book, including a Venezuelan girlfriend who also happens to be Black. It should be mentioned here that Dés has also written a wacky family history cum cookbook, which is mostly about his mother and the recipes she cooked for her Spanish grandchildren, for whom the notion of "nagyi fözte" ('Grandma's cooking') represents their own Hungarian identity. In that book, too, there is a lot about Kádár's Hungary and, in fact, even the recipes represent that time in many ways.

On the one hand, then, Dés' works as a translator of Gabriel García Marquez, Alejo Carpentier, Mario Vargas Llosa, etc., like his other international experiences, all endow his novel with more than a veneer of liberal cosmopolitanism. On the other hand, I would have settled for 
Fenyo, Mario. "Dés, Mihály. 2013. Pesti barokk ['Budapest-Style Baroque']. Budapest: Magvető. 552 pp."

Hungarian Cultural Studies. e-Journal of the American Hungarian Educators Association, Volume 8 (2015): http://ahea.pitt.edu DOI: 10.5195/ahea.2015.195

a less heavy-handed approach to the Kádár regime and less frequent mentions of the "salami tactics," the "gayest barracks in Eastern Europe" and other such trite epithets that by now have grown stale. Still, I highly recommend this book, not just for the sake of its insights into the social history of the Kádár era but also, and especially, because it is fun to read. In my eyes Mihály Dés deserves to be a member of any writers' association. 